\title{
Typological Study of Financialized Housing in Chile: Verticalization in Estación Central
}

\author{
José-Francisco Vergara-Perucich \\ Centro Producción del Espacio, Universidad de Las Américas, Manuel Montt 948, Providencia, Chile
}

Received January 28, 2021; Revised March 22, 2021; Accepted April 18, 2021

\section{Cite This Paper in the following Citation Styles}

(a): [1] José-Francisco Vergara-Perucich, "Typological Study of Financialized Housing in Chile: Verticalization in Estación Central," Civil Engineering and Architecture, Vol. 9, No. 3, pp. 611-624, 2021. DOI: 10.13189/cea.2021.090305.

(b): José-Francisco Vergara-Perucich (2021). Typological Study of Financialized Housing in Chile: Verticalization in Estación Central. Civil Engineering and Architecture, 9(3), 611-624. DOI: 10.13189/cea.2021.090305.

Copyright $\bigcirc 2021$ by authors, all rights reserved. Authors agree that this article remains permanently open access under the terms of the Creative Commons Attribution License 4.0 International License

\begin{abstract}
In urban studies, the financialization of housing has become a key aspect in understanding the affordability problems faced by households around the world. The financial interests involved in housing production shift the focus from the provision of a residential habitat to the creation of long-term fixed income capital. However, these studies of high interest to architects have not been studied from the perspective of design and spatial typologies of financialization. This study reviews architectural typology using planimetric information of houses whose main objective is to become profitable products. Based on the critical review of 37 high-rise housing projects in the commune of Estación Central in Santiago de Chile, a matrix of analysis of the main characteristics of studios and one-bedroom flats is constructed to describe the financed housing unit category in a verticalization model. The research revised official sources for each project, reviewing plans, permits and environmental impact statements that describe the works and their specific analysis. The case study is of high interest because they were installed in a low-income commune of Greater Santiago, capitalized the sector by attracting new residents from higher-income communes, and transformed the urban landscape through residential buildings that are on average 30 stories high. As part of the results, 24 typologies are extracted then summarized in two general types of flats for financial speculation. Also, each case was analyzed by its financial value using the NPV and IRR techniques for economic assessment of investments exposing how profitable these types of projects are. The investment in real estate capital has an impact on the design
\end{abstract}

and formation of typologies arranged for financial speculation with housing. The results of this research illuminate a discussion on the role of architects in the development of housing for financial purposes and propose a discussion on the importance of understanding the architectural aesthetic of financing as a highly relevant disciplinary problem.

Keywords Financing, Housing, Architecture, Typology, Verticalization

\section{Introduction}

Leilani Farha argues that the financialization of housing occurs when it becomes a vehicle for investment to create wealth by assuming a commodity status instead of a social good which undermines its role as a human right [1]. The financialization of housing has social effects that are covered in the literature [2]-[4], which in synthesis are based on economic situations, the dynamics of global financial capital, and political implications [5]. From an architectural perspective, specific effects are also produced on the typologies that characterize a house that has been designed to be an investment vehicle over a space for developing a habitat for families and individuals. However, the typological characterization of housing as a commodity has not been fully discussed in the literature as an architectural problem [6]. The present article seeks to present findings that inform this problem, providing a 
typological characterization of financed housing in Chile. This analysis focuses on housing projects developed by the real estate market that, based on the behavior of some consumer groups and the industry itself, define typologies whose main objective is to buy-to-let [7]. From an initial statistical study based on information from the Santiago Real Estate Registry, the Environmental Evaluation Service, and specialized literature, a set of projects with their respective architectural typologies were drawn up to determine the characteristics of housing models prepared for financialization by investors. Specifically, the analysis focused on models of large-scale verticalized housing located in the Estación Central district of the Metropolitan region in Chile [8], [9], due to the interest that these cases have aroused in the specialized press as examples of speculation and rent where the habitat is subordinated to the profitability of the investment. Also, the interest on the relationship between financial institutions and real estate is a matter of relevant interest in the recent international literature [10].

Recently, different approaches have helped frame the problem of financialized housing in Chile. Daniel Santana analyzed financialization from the perspective of the mechanisms that use debt to review how access to housing also leads to accelerated household indebtedness [11]. Ivo Gasic explored the relationship between financial actors and the acquisition of urban land as a mechanism for action by big business on the housing market [12]. In the case of Chile, the state has been identified as one of the main actors promoting a dynamic development of urban extractive industries through the process of housing financialization by means of decrees and subsidies that provide liquidity to the financial system [13]. For Antonio Daher, this process in Chile is in line with a global demand to facilitate the relationship between real estate production and the financial market [13]. For Lisett Márquez López, one of the main spatial results of the financialization of the Latin American city is verticalization [14]. To a large extent, studies on the financialization of housing are framed in terms of linking the global problem of indebtedness and the exclusion of inhabitants, rather than in the specific spatial effects of this urban process oriented towards income from real estate capital. To help complete the analyses of financialization, a spatial view is provided and, towards the creation of an analytical architectural category, the present article develops a synthesis of what housing is like and whose purpose is to be an investment vehicle over a social good based on empirical evidence.

\subsection{Financialization of Housing}

For Engelbert Stockhammer, financialization occurs when a regime of financial accumulation in fields outside the purely financial area assumes financial practices and methods as its own, thus aligning its objectives with those trends [15]. One of the symptoms Stockhammer highlights of the emergence of financialization is the increase in household debt. Different interpretations of financialization have developed from Stockhammer's approach, one of which is the process of housing financialization. For Raquel Rolnik, the process of housing financialization is centered on the creation of owners through the development of mortgage loans, which, because they are registered in the banking system, generates barriers to acquire secure tenure. This, in turn, leads to the denial of a human right, deprivation and displacement, and pushing towards other types of housing based on expensive lettings and informality [16], [17]. It is precisely in this process that the financial world finds the structural deficit of housing a space for exploiting rents from indebted households through financial instruments, converting homebuyers into contributing assets to capitalize on the large financial companies that, through the production of housing, increase their profits [18]. Though the financialization of housing is a global phenomenon, it has visible local effects.

Rodrigo Cattaneo detailed how the housing financialization process occurred in Chile, indicating that after 2001 capital market reform, when the participation of large investment groups in housing production was intensified through the creation of real estate investment branches in financial companies, the acquisition of property from others, and the diversification of the sources of financing of the housing industry itself, financial actors entered to generate greater influence than before 2001, with special emphasis on the consolidated areas of Greater Santiago. According to Cattaneo, this process will be spatialized with a specific morphology, tending to verticality and the development of residential models oriented towards the low and middle class sectors [19]. In Jorge Vergara's study, it is indicated that the development of this type of vertical residential buildings was concentrated on 11 communes in Greater Santiago, generating doubts as to whether the proliferation of verticalized housing would adjust to the real load capacity of the communes and neighborhoods where they are inserted [20]. A study carried out in the commune of Santiago Centro for the Santa Isabel axis found that residents of the area can hardly pay the prices of housing and that these values are reserved for the highest income deciles. The same study found higher profitability in investing in housing than in other financial instruments such as the APV or even stock market shares measured by the yield coefficient [21], [22]. Verticalization as the preferred urban form for the development of financial investment vehicles in the housing sector is presented as a key study typology.

The composition of verticalized buildings obeys a grammar of power where enclosure, visual weight, size, isolation from the environment, symmetry in design and verticality make up some political dimensions of the design [23] [24]. Globalized financial power makes it very 
difficult for social movements to effectively oppose the financialization of housing, given that the urban planners and architects who participate in this process do not necessarily occupy comfortable positions in society, nor do they have many employment options to seek other sources of income instead of having to operate in favor of large capital investment circuits. [25]. The verticalization of cities is part of an aesthetic and power phenomenon that seeks in part to generate a specific urban volumetric experience oriented towards big capital, and which conquers the air of the city with the individual object, represented vertically, over the collective horizontally represented buildings, with accelerated verticalization being a neo-liberal representation. The spatial and symbolic composition of financialization is particularly related to verticalization, although analyses of it have not dealt with the architectural scale, and have mainly being in urban design and planning studies.

For Peggy Deamer, the history of architecture is also the history of the capital, whose relations deserve careful observations on how one is represented in the other to determine whether the architectural language is autonomous and how the relationship of economic dependence between architects and the owners of the capital ends up shaping the spatial decisions and, in practice, the city's own language [26], [27]. Since, today, financial capital is the main source of global power. The relationship between the architecture resulting from that power and its location is the key to understanding the current global scenario, considering architecture is the spatial manifestation of economic history of the world. In this sense, Deyan Sudjic's interpretation seems to be precise. He indicated, in 2006, that after the fall of the Twin Towers, for the first time the tallest building in the world was no longer in the West, but in Malaysia: the Pretonas Towers, designed by a Western architect with Asian labor [28]. As at 2020, the tallest building in the world is Burj Khalifa in Dubai. For Sudjic, since architects work for the power of capital, in practice, they are the ones who have shaped the world today. The disciplinary responsibility in this respect is no less important and therefore it is key to deepening the spatial relationship generated by the financialization of housing. Functionality and economic rationality have historically conditioned architecture to remain in a position of conflict with aesthetics, with well-known disciplinary disputes when it comes to beauty, but without losing an aesthetic stance [29] which generates a policy of its own activity to shape a social sphere that is configured from a set of typological decisions.

The aesthetics of financialization in housing lies in the results of housing production as if it were a commodity. Some clues to these typologies in Chile were provided by Assadi, Pulido and Zapata in 2008, indicating that the real estate machine for producing architecture has a set of predefined methods based on market studies and potential clients that leave very little room for the creativity of architects, who had to follow these rules in order to produce what can be marketed in the city. These typologies, which are ideal for the Chilean real estate market, can now be explored in more detail thanks to advances in data transparency for projects with a public impact, such as high-rise buildings.

\section{Materials and Methods}

The case study consists of 37 private housing buildings in the commune of Estación Central, which are popularly called vertical ghettos [30] developed between 2011 and 2019 (Figure 1). These buildings are of great interest for the analysis of financialization because, first, their verticalization is developed in a space delimited between 5 de Abril Avenue, Las Rejas, Ecuador and Ruiz-Tagle Street, completing about 180 hectares for the location of 28,164 housing units, on $135,330{ }^{\mathrm{m} 2}$ of land, for a declared investment of nearly $\$ 900$ million, executed by different private companies in a central district of Santiago, which provides a high value of the location although Estación Central is the 9th over 34 districts with higher multidimensional poverty level based on CASEN 2017. One of the most interesting aspects of this case is that of the total sales of flats registered at the Santiago Real Estate Conservative between 2011 and 2019 when $20 \%$ of the buyers acquired more than one flat in the district of Estación Central. Added to this is another relevant factor: the average income of households in the commune of Estación Central is 35.2 UF, but the value of mortgage dividends for homes that have been built in the commune, for any of its types, allows their acquisition for the income levels of households that already exist in the commune, as shown in Table 1. In other words, these residential buildings have not been developed to meet the housing demand of the district's residents, but rather for people from other municipalities, thus promoting gentrification [31]-[33] or investification. That is, the purchase of homes for rent by people who would not live in the neighborhoods where they invest [34], [35].

Multiple clients purchase the super-dense buildings of Estación Central present typologies of financialized housing for investment purposes. They are intended to obtain long-term income, rather than to live in such spaces. Most people who bought more than one property in the commune bought the smaller flats. Based on the information reviewed in the InCiti.com data, the section of flats with less than $37 \mathrm{~m}^{2}$ represents $31 \%$ of the buyers who invested in two or more flats in the commune for the period under study. These flats correspond to studios (without bedrooms) or one-bedroom flats. It is for this reason that the architectural typological study of these cases will focus on the varieties that exist in the commune for that specific 
section.

This research is deductive in that it reviews a case from an existing theoretical framework that refers to the financialization process in housing. This theoretical framework offers an entry point to a specifically architectural analysis of how housing is developed typologically to enable such processes. This study offers an inverse path, from the architectural object itself designed for financialization, instead of financialization as a global phenomenon. This gives this research an exploratory character applying quantitative and qualitative methods [36]-[39].

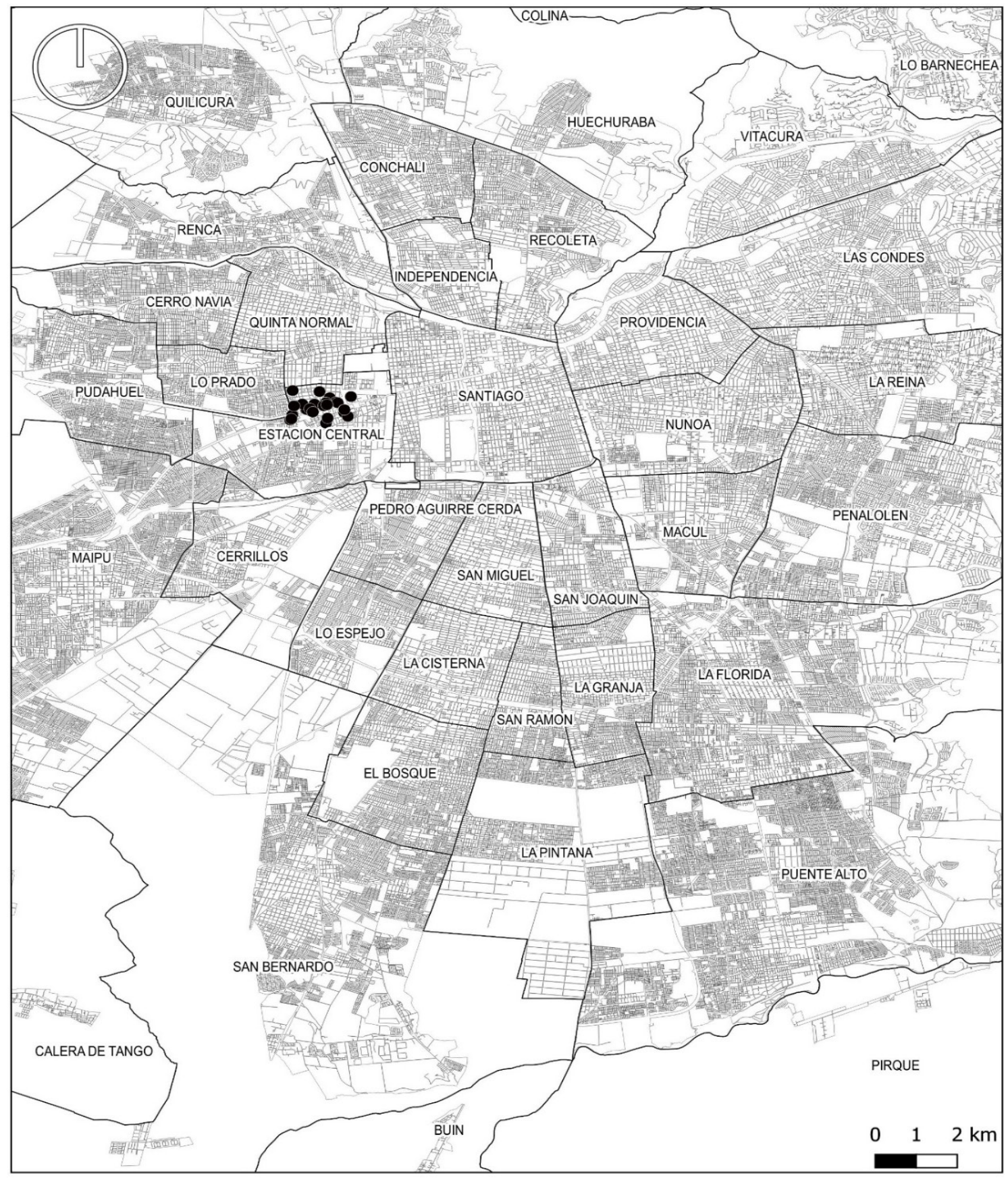

Figure 1. Location of cases of residential housing buildings studied for this research: Source Environmental Assessment Service. 
Table 1. Ratio of household income determined by CASEN 2017 survey, value of housing according to size brackets based on InCiti.com and estimated value of dividends in relation to income for annual rates of $4 \%$, financing $90 \%$ of the housing over a 30 -year period. Source: Author based on CASEN 2017 survey and www.inciti.com

\begin{tabular}{|c|c|c|c|c|c|c|}
\hline $\begin{array}{c}\text { Type of Home Central Station } \\
\text { Commune }\end{array}$ & Averages & 1 person & 2 persons & 3 people & 4 persons & 5 people \\
\hline Household income in UF & 35,20 & 15,01 & 26,15 & 28,25 & 37,34 & 34,78 \\
\hline $30 \%$ of income & 10,56 & 4,50 & 7,84 & 8,48 & 11,20 & 10,43 \\
\hline \multirow{2}{*}{$\begin{array}{l}\text { Average value of apartments } \\
\text { according to size }\end{array}$} & Overall average & $15-22^{\mathrm{m} 2}$ & $23-36 \mathrm{~m} 2$ & $37-50 \mathrm{~m} 2$ & $51-64 \mathrm{~m} 2$ & 65 -more ${ }^{\mathrm{m} 2}$ \\
\hline & $1.518,00$ & $1.121,00$ & $1.350,00$ & $1.677,00$ & $1.819,00$ & $1.676,00$ \\
\hline $\begin{array}{c}\text { Dividend with } 4 \% \text { annual rate at } 30 \\
\text { years for } 90 \% \text { property value }\end{array}$ & 6,52 & 4,82 & 5,80 & 7,21 & 7,82 & 7,20 \\
\hline $\begin{array}{c}\text { Dividend to income ratio } \\
\text { (recommended, no more than } 30 \% \text { ) }\end{array}$ & $62 \%$ & $107 \%$ & $74 \%$ & $85 \%$ & $70 \%$ & $69 \%$ \\
\hline
\end{tabular}

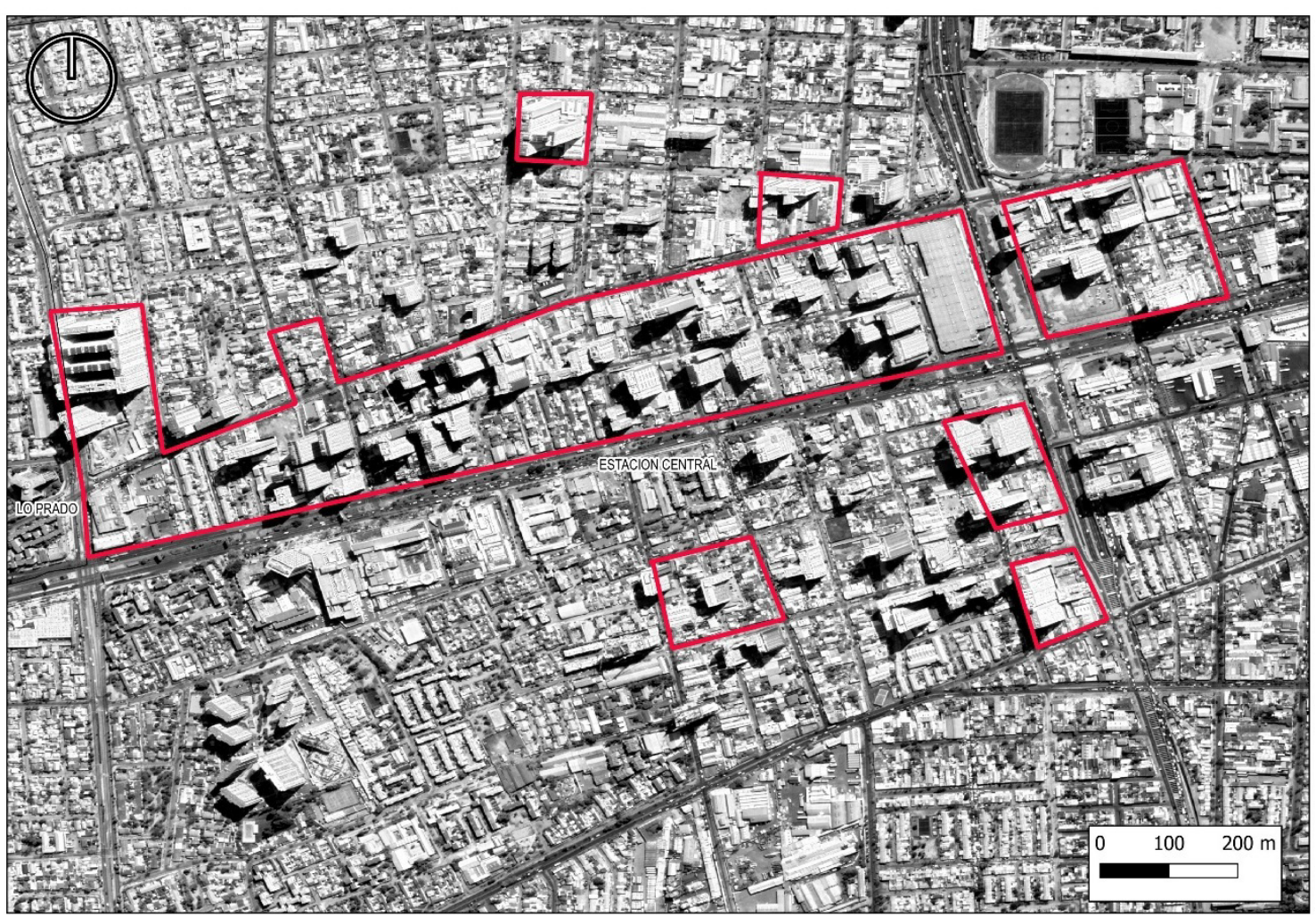

Figure 2. Distribution of project survey areas for study in the commune of Estación Central: Source: Own elaboration based on data from the Environmental Evaluation Service.

The quantitative approach has been developed in the first instance to determine the buildings to be studied. For this purpose, a series of steps were followed, starting with the gathering of official information to review the architectural plans of high-rise buildings that are potentially subject to financialization. For this purpose, access was gained to data from the Environmental Evaluation Service, where all large projects in the residential real estate sector must be evaluated by entering an Environmental Impact Statement, in which all backgrounds of the project must be included, including plans, permits and investment amounts, among many other aspects [40]. This public information allowed people to know that 37 residential real estate proposals have been approved in the Estación Central commune (Figure 2) and then marketed, contributing to 28,164 declared housing units on $135,330 \mathrm{~m}^{2}$ of land on which $1,382,335 \mathrm{~m}^{2}$ of land had been built, for a declared investment amount of $\mathrm{UF}^{1} 24,315,799$, by different real estate companies, with special participation by SuKsa (16 projects), Fundamenta (4 projects), Paz (3 projects) and Eurocorp ( 2 projects). On average, the buildings reviewed are 30 floors high, with flats averaging $38 \mathrm{~m}^{2}$ in relation to the available supply of useful surface area for sale. It is important to mention that the information studied are based on projects entered into the Environmental Evaluation Service, which do not necessarily represent the works that were finally built ${ }^{2}$.

1 UF is an acronym for Unidad de fomento, an indexed measure of value by pricing it to Chilean Pesos adjustable by the CPI daily. Its value converted to US dollars is 39.9 at 25-01-2021.

2 Recently, five of these buildings were declared as illegal by the Supreme Court because the application of the regulatory framework was contradictory with the general law of urbanism and construction: 
Some inconsistencies have been found in the review process between what the Environmental Impact Statements of the companies say and what the plans show or what is indicated in the building permits issued by the Built Environment Director of the Municipality of Estación Central. Above all, the study has been done with the available architectural plans. In this quantitative instance, the data on the permits were reviewed and the planimetries unified. It is important to mention that the planimetric sources have been anonymized to avoid the stigma that could be attached to the people living in these departments.

With the set of plans obtained, the available typologies that present variability in the distribution of space for models of studios and one-bedroom flats were analyzed. A total of 34 models were reduced to 24 organizational typologies whose designs represented the typologies that were excluded from the first collection. Many floor models were repeated in the different buildings studied, so the sample reduction sought to facilitate analysis as well as to synthesize the results. The analysis of the models chosen was based on an initial visual study of planimetric organization patterns based on defining the (i) location of the bathroom, (ii) location of the kitchen, (iii) terrace, (iv) type of division for the bedroom, (v) type of wardrobe and (vi) location of the entrance door. This made it possible to generate a generic initial filter of the models observed, resulting in the definitive sample being 15 representative typologies of the studios category and nine representative typologies of the one-bedroom category.

For the specific analysis of the architectural form, reference is made to Baker, Ching and Prokopska, together with a social science approach to the study of visual documents developed by Rose. For Baker, form is the way through which architecture and its organization are expressed when it comes to generating a rational geometric composition. It is often developed intuitively, but, through sequential analysis, it allows the decisions behind the designs to be interpreted [41]. To organize the analysis, Baker suggests identifying some key patterns with which to guide the study of form, starting with whether the space is linear or central, identifying the dynamics of form, determining whether or not there are nuclear systems or whether there is linearity, reviewing the existing axialities or the connections between spaces that can also generate formal distortion. Deepening Baker's approach, Ching suggests classifying forms, modes of organization, circulations, proportions, scale and space itself [42]. Because the study presented here focuses only on units of departments, many of the clarifications developed by Ching and Baker will not be applied. Prokopska offers a way of filtering the aspects that are developed in a morphological-architectural analysis. First, define the main

https://www.latercera.com/nacional/noticia/corte-suprema-ratifica-ilegali dad-de-los-guetos-verticales-en-estacion-central/OYN5C7ONOBATTC KID376A2RJNE/ characteristics of the universe of objects observed (in this case, the departments) and for each characteristic to identify its particular variations; then, generate a series of possible combinations between the variations; finally, carry out a sample reduction and determine a generalizable morphological model [43], which in this case will be called a housing unit financialized in a verticalization model. To illustrate the adaptation of the contributions of Baker, Ching and Prokopska, Table 2 represents a methodological reference table.

This organization of visual analysis is eminently compositional as Rose suggests, as it reviews the content and spatial organization of the planimetries reviewed. It is also social as it combines the analysis with the economic relations that can be derived from an analysis of price valuation that is incorporated in this study [44]; an unavoidable component as it is in the process of reviewing financialization factors. The layout of the results of this study is a visual analytical content that contributes to the development of critical approaches to how financialization is spatialized and generates modes of inhabitation suitable to the creation of wealth from property development.

To depict the financial value of the typologies analyzed two techniques were applied: the net present value and the internal rate of return. The net present value is a technique that calculates the present value in money of a certain number of future financial flows generated by an investment. It is calculated by applying a current discount rate to all future cash flows, simulating what the gains would be if the cash flows were brought to the present to compare these gains with the initial investment. The discount rate (i) is the result of the product between the weighted average cost of capital (WACC) and the inflation rate for the period. For these projects, a discount rate of $8 \%$ was applied, although the current discount rate is about $7 \%$; so these calculations deliver more conservative results. The NPV formula used in this study is:

$$
\mathrm{NPV}=\sum \mathrm{jn}[-1+\mathrm{Rj}(1+\mathrm{i})-\mathrm{n}]
$$

where,

$$
\begin{gathered}
\mathrm{Rj}=\text { net cash flow in the " } \mathrm{j} \text { " period } \\
\mathrm{n}=\text { number of periods } \\
\mathrm{i}=\text { discount rate }(8 \%)
\end{gathered}
$$

In Chile, the General Law of Environment number 19300 defines as compulsory the submission by owners and managers of all the information pertaining to real estate projects. This information includes investment amounts for the project, work force involved, work days based on a Gantt Scheme, legal information, blueprints, permissions by local authorities, exact location of the projects, square meters per sections, $\mathrm{CO}_{2}$ emissions, and a plan of the measures to reduce the environmental impact of the project. In this case, the data provided by real estate companies is complemented by the pricing of property transactions registered in the Real Estate Registry Office, information that was systematically organized by the private company InCiti.com. Therefore, to assess the profitability of the 
projects observed, the data was accurately obtained from the original source of information. Complementary, a profitability estimation was applied to each flat analyzed based on its typologies using the internal rate of return technique or IRR. The internal rate of return reviews the geometric mean of the return on investment to determine the value of the opportunity. The higher the internal rate of return, the higher the expected return on an investment, which thus determines whether the investments are worthwhile or not. Investments whose IRR is higher of $12 \%$ in real estate are considered as very good opportunities. Its calculation is based on the following formula:

IRR, such that, $\sum j=0 n R j n(1+I R R) n=N P V=0$ where,

$$
\begin{gathered}
\mathrm{Rj}=\text { net cash flow in the " } \mathrm{j} \text { " period } \\
\mathrm{NPV}=\text { net present value } \\
\text { IRR }=\text { internal rate of return. }
\end{gathered}
$$

As mentioned before, from the collection of data from the environmental statements, the projects analyzed presented a timetable of works, a general estimation of value for the investments and the architecture plans which make it feasible to calculate the average cost of production for each building. Also, a complementary dataset was consulted in order to identify the actual final pricing of the departments registered in the transaction system, whose information is available in www.inciti.com, a private service to track the history of residential projects in the Metropolitan region of Chile. A third source of data is based on www.portalinmobiliario.cl, from where the rental prices of flats in the area under study were collected to elaborate an assessment of how profitable the investment in this area would be in the long run of 30 years. The application of these techniques is summarized in Table 4, as one of the contributions of this article in relation to the financialization of verticalized architectures of housing.

Table 2. Summary of architectural analysis procedure to determine specific characteristics of housing units financialized in a verticalization model for buildings in Central Station.

[General Type]

Studio, 1 bathroom

1 Bedroom, 1 Bathroom

2 Bedrooms, 1 Bathroom
Verticalization Model Financed Housing Unit

[Feature]

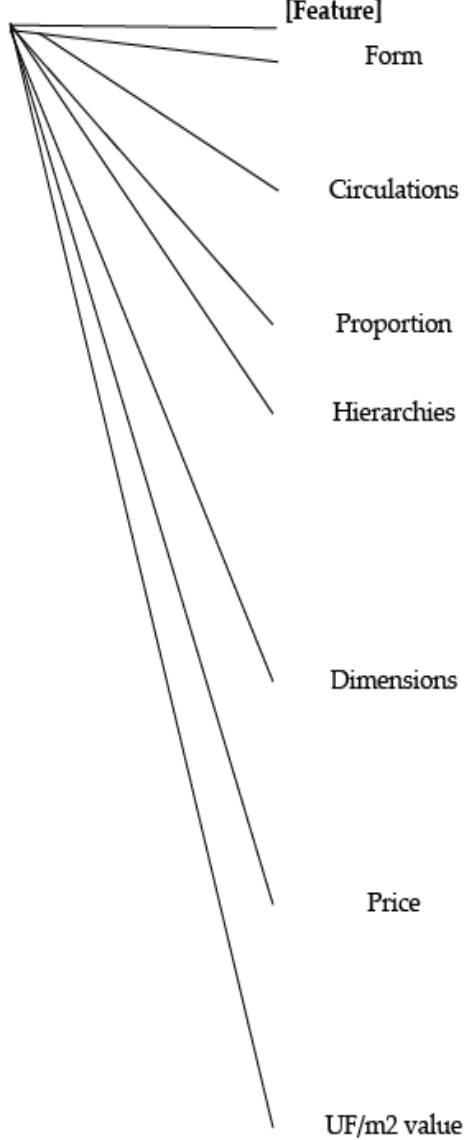

[Variations]
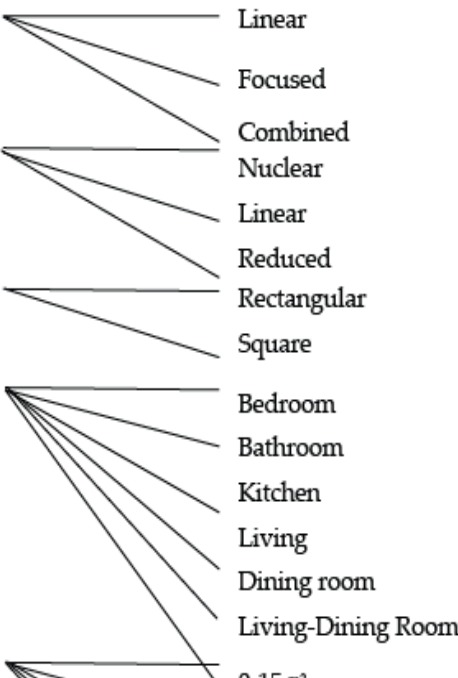
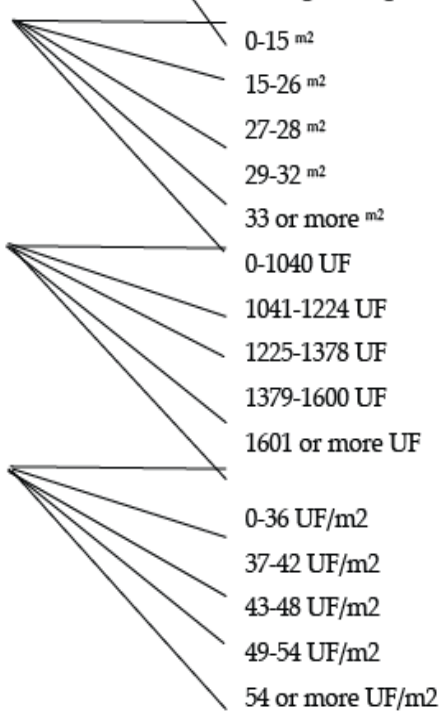


\section{Results}

In the process of methodological application, two architectural models have been distinguished during the analysis: studios and 1-bedroom flats. To organize the analysis, an analytical matrix was developed which, on the one hand, presents the architectural plans for each model that synthesize the observed sample (Figure 3) and, on the other hand, systematizes the analysis by categories to identify the dominant characteristics of each sample (Table 3 ). With this analysis, two synthetic planimetric models of housing units financed in a verticalization model were drawn up, which can be seen in Figure 3.

In the study, 16 different dimensions measurable in square meters were found in analyzed departments ${ }^{3}$ from a total of 3,894 units studied. The average value of the total typologies studied was UF 1,250 for an average surface area of $24.75 \mathrm{~m}^{2}$. From the gross amounts declared by the companies before the Environmental Evaluation Service, it was determined that the production cost, based on the investment per project of each $\mathrm{m}^{2}$, was $17.33 \mathrm{UF} / \mathrm{m}^{2}$, while the average sales value of these same projects was 48 $\mathrm{UF} / \mathrm{m}^{2}$. That is, the expected profit for each square meter built would generate for the companies a $175 \%$ gross capital gain in relation to the initial investment, with an estimated average IRR of 59\%, determining that financially, these projects are highly profitable. On average, the net present value income mediated for these projects is close to 6 million dollars, although a couple of projects had returns that could have faced some profitability problems in relation to the declared investment and the obtained sales.

From the survey of architectural plans, 24 dominant models were observed, as indicated in Table 3. For the studios, the dominant form is linear, where a corridor of no more than 5 meters in most cases serves a linear kitchen attached to a dividing wall with another department, facing a bathroom of 1.6 meters wide on average, with a space for the bed that is about $10 \mathrm{~m}^{2}$, being this the hierarchical space of the housing unit. They are proportionally rectangular and most of the dimensions observed are located in the segment between 15 and $26 \mathrm{~m}^{2}$ with $73 \%$ of the plans observed and between 29 and $32 \mathrm{~m}^{2}$ for $27 \%$ of the plans. Prices varied mainly between UF 1041 and 1600, with the most dominant range between UF 1379 and UF 1600. Most of the flats with one bedroom have a central shape with reduced circulation, that is, without apparent corridors or passageways but with a set of areas of use that face each other and share the same circulation. Most of these typologies are square, with the bedroom occupying the

3 The method of measurement carried out in takes de dimensions between architectural axes of main walls of the plan, according to the General Ordinance of Urbanism and Construction to define the length of useful surface of a house. most space, followed by the living-dining room. As for their dimensions, most of them are between 29 and $32 \mathrm{~m}^{2}$ $(54 \%)$ and to a lesser extent there are models of 27 to $28 \mathrm{~m}^{2}$ $(25 \%)$ and 15 to $26 \mathrm{~m}^{2}(8 \%)$. Most of the values for this typology range from UF 1379 to UF 1600 .

As this is a financialization study, it is essential to identify how these typologies operate from an investment income perspective. Following the property investment model illustrated by Felipe Yaluff [7], the profitability of a buy-to-let scheme was reviewed, taking as an assumption a bank purchase that finances $20 \%$ of the initial payment by a loan for general purposes at an annual rate of 5\% for 36 months; mortgage loan at an annual fixed rate of $4 \%$ for a period of 30 years and the resulting dividends were used to simulate profitability against letting prices using a future projection based on an annual CPI of $3.63 \%$, corresponding to the average annual variation of the CPI between 2010 and 2020 in Chile [45]. Table 4 summarizes the results of the financial analysis of these typologies. In the metropolitan region of Santiago, $76 \%$ of the flat owners purchased their housing units via mortgage or financial instruments (CASEN 2017). After the 2008 financial crisis, in Chile, financial institutions started to finance only $80 \%$ of the property price and in some exceptional cases $90 \%$ as a measure to reduce the risk for banks specifically. So mortgages cover that portion of the property, and the residual value must be paid with alternative means such as savings or loans from other financial institutions. Using these conditions, an assessment is performed to identify the profitability of these typologies (ordered by square meters in the first column). The assumption is that each buyer receives a mortgage for $80 \%$ of the property for 25 years of indebtment (300 months) and the residual $20 \%$ is financed by a regular loan for 4 years of indebtment ( 48 months), at a rate of $4 \%$ yearly for the mortgage and $18 \%$ yearly for the regular loan. Complementarily, a projection in the long term of the rental incomes for each typology is performed, adjusting the rent value yearly using the average CPI of the last 10 years. The cash flow of this business is assessed using the Net Present Value and the Internal Rate of Return for 300 months in the future to identify the profitability of this investment. Based on the models studied, the only one with a negative NPV is the $16 \mathrm{~m}^{2}$ typology; the rest showed significant returns on invested capital. In this financial analysis, for the long-run, the profitable typologies have an average IRR of $23 \%$, a more competitive asset than an investment in the stock market or even in the creation of a small business. This is complex, because the captive demand for housing based on the structural deficit in Chile - about half million, may undermine the use of investment capital for creating new companies and therefore jobs and diversification of economy. People having incomes for investing would prefer to do it in a low-risk and profitable activity as buy-to-rent instead of risking their capital for innovative initiatives and endeavors. Housing as a moneymaking machine not only affects the access of lower income household to property ownership but also provides 
a riskless scenario for investors who can prefer these initiatives to venturous ones. A deeper reflection is required on how the absence of social security influences the decision of investing in this type of businesses. In Chile, the pension and health systems are in crisis, both are based on privatized companies who are mainly oriented to profit with their services and having an asset as a property may serve as capital injection for pay a cancer treatment or for complementing the failed pension system of AFPs.

Considering the relevance of financial institutions in allowing the business of buy-to-let, interest rate and monetary policy should be part of this diagnosis, as they are correlated (Table 5). On the one hand, the high dependence of financial instruments for purchasing housing, which implies that only people with high purchasing capacity may rely on the bank for long-term credit (such as mortgages), may exclude households trapped between the unsuitability for social housing provision and the long-term mortgages. A non-financialized solution is required for those segments whose credit capacity impedes them from accessing the secure tenure of housing. On the other hand, a different approach to ensuring secure tenure may be led by the state by implementing a public housing stock, which in Chile currently does not exist. The state as housing owner may have different objectives from investors in buy-to-let models and may lead to attempts to solve the problem by creating a condition in which housing prices are defined by financial instruments, instead of human needs and the actual purchasing power of those households without access to ownership.

Table 3. Matrix for the analysis of typologies and synthesis of results. The most relevant resulting factors are indicated with an asterisk for each characteristic

\begin{tabular}{|c|c|c|c|c|}
\hline Feature & Modalities & Studio & 1 Bedroom 1 Bathroom & $\begin{array}{l}\text { Synthesis of the Unit of } \\
\text { Financed Housing in } \\
\text { Verticalization Model }\end{array}$ \\
\hline \multirow{3}{*}{ Form } & Linear & $0,67 *$ & - & $0,67^{*}$ \\
\hline & Focused & 0,27 & 1,00 & 1,27 \\
\hline & Combined & 0,07 & - & 0,07 \\
\hline \multirow{3}{*}{ Circulations } & Nuclear & 0,13 & 0,44 & $0,58 *$ \\
\hline & Linear & 0,40 & - & 0,40 \\
\hline & Reduced & 0,47 & 0,56 & 1,02 \\
\hline \multirow{2}{*}{ Proportion } & Rectangular & $0,87^{*}$ & 0,11 & 0,98 \\
\hline & Square & 0,13 & $0,89 *$ & $1,02 *$ \\
\hline \multirow{6}{*}{ Hierarchies } & Bedroom & $1,00^{*}$ & $1,00^{*}$ & $2,00 *$ \\
\hline & Bathroom & 4,00 & 4,00 & 8,00 \\
\hline & Kitchen & 3,00 & 3,00 & 6,00 \\
\hline & Living room & - & - & - \\
\hline & Dining room & - & - & - \\
\hline & Living-Dining Room & 2,00 & 2,00 & 4,00 \\
\hline \multirow{5}{*}{ Dimensions } & $0-15 \mathrm{~m}^{2}$ & - & - & - \\
\hline & $15-26 \mathrm{~m}^{2}$ & $0,73^{*}$ & 0,08 & $0,80^{*}$ \\
\hline & $27-28 \mathrm{~m}^{2}$ & - & 0,25 & 0,25 \\
\hline & $29-32 \mathrm{~m}^{2}$ & 0,27 & $0,54^{*}$ & $0,81 *$ \\
\hline & 33 or more $\mathrm{m}^{2}$ & - & - & - \\
\hline \multirow{5}{*}{ Price } & 0-1040 UF & 0,06 & - & 0,06 \\
\hline & 1041-1224 UF & 0,19 & 0,10 & 0,29 \\
\hline & $1225-1378$ UF & $0,42 *$ & 0,32 & $0,74^{*}$ \\
\hline & $1379-1600 \mathrm{UF}$ & 0,33 & $0,57^{*}$ & $0,90 *$ \\
\hline & 1601 or more UF & 0,00 & 0,00 & 0,01 \\
\hline
\end{tabular}


Table 4. Estimation of profitability according to typologies and dimensions-based on investment model for rental properties in buildings evaluated in Estación Central. The cost of the investment includes the total value of the mortgage and the footprint. The total income from rentals considers the value of rent in the current market, adjusting for a 30-year projection for an annual CPI of $3.63 \%$, based on the average CPI of the last 10 years. Values are presented in USD 2021

\begin{tabular}{|c|c|c|c|c|c|c|c|}
\hline $\begin{array}{l}\text { Dimensions } \\
\qquad\left(\mathrm{m}^{2}\right)\end{array}$ & $\begin{array}{l}\text { Value } \\
\text { (USD) }\end{array}$ & $\begin{array}{l}\text { Mortgage Credit } \\
\text { (USD, 80\%) }\end{array}$ & $\begin{array}{c}\text { Footnote } \\
\text { (USD, 20\%) }\end{array}$ & $\begin{array}{l}\text { Total investment } \\
\text { cost (USD) }\end{array}$ & $\begin{array}{c}\text { Total income } \\
\text { from rentals } \\
\text { (USD) }\end{array}$ & $\begin{array}{c}\text { NPV } \\
\text { (Discount Rate } \\
8 \% \text { ) }\end{array}$ & IRR \\
\hline 37 & 55,950 & 44,775 & 11,174 & $-90,447$ & 166,596 & 13,115 & $36 \%$ \\
\hline 35 & 51,837 & 41,477 & 10,360 & $-83,798$ & 159,301 & 12,898 & $38 \%$ \\
\hline 31 & 54,359 & 43,495 & 10,864 & $-87,875$ & 127,828 & 7,608 & $25 \%$ \\
\hline 30 & 52,962 & 42,370 & 10,592 & $-85,617$ & 123,144 & 7,202 & $25 \%$ \\
\hline 29 & 48,849 & 39,072 & 9,778 & $-78,969$ & 122,727 & 8,022 & $28 \%$ \\
\hline 28 & 55,445 & 44,348 & 11,097 & $-89,632$ & 105,488 & 4,005 & $19 \%$ \\
\hline 26 & 44,271 & 35,424 & 8,846 & $-71,567$ & 109,285 & 6,978 & $27 \%$ \\
\hline 24 & 45,202 & 36,162 & 9,040 & $-73,073$ & 94,067 & 4,482 & $22 \%$ \\
\hline 23 & 50,207 & 40,158 & 10,049 & $-81,164$ & 79,327 & 1,184 & $16 \%$ \\
\hline 22 & 46,288 & 37,015 & 9,273 & $-74,829$ & 78,604 & 1,916 & $17 \%$ \\
\hline 21 & 43,223 & 34,571 & 8,652 & $-69,874$ & 76,541 & 2,263 & $18 \%$ \\
\hline 20 & 44,077 & 35,269 & 8,808 & $-71,254$ & 68,323 & 840 & $15 \%$ \\
\hline 19 & 39,537 & 31,622 & 7,915 & $-63,915$ & 68,575 & 1,853 & $17 \%$ \\
\hline 18 & 39,304 & 31,428 & 7,876 & $-63,539$ & 62,063 & 921 & $16 \%$ \\
\hline 17 & 33,058 & 26,462 & 6,596 & $-53,440$ & 64,998 & 2,705 & $20 \%$ \\
\hline 16 & 55,872 & 44,698 & 11,174 & $-90,322$ & 22,284 & $-8,638$ & $4 \%$ \\
\hline
\end{tabular}

Table 5. Pearson correlation between average apartment prices and monetary policy interest rate Central Bank Chile, and mortgage placements. Source: Author, based on Central Bank of Chile data.

\begin{tabular}{ccc}
\hline Average apartment price per square meter & $\begin{array}{c}\text { Monetary policy interest rate Central } \\
\text { Bank Chile }\end{array}$ & Mortgage placements \\
\hline Pearson correlation & $-0,375$ & 0,305 \\
\hline Sig. (one-tailed) & 0,000 & 0,000 \\
\hline Number of periods (2008-2019) & 133 & 133 \\
\hline
\end{tabular}



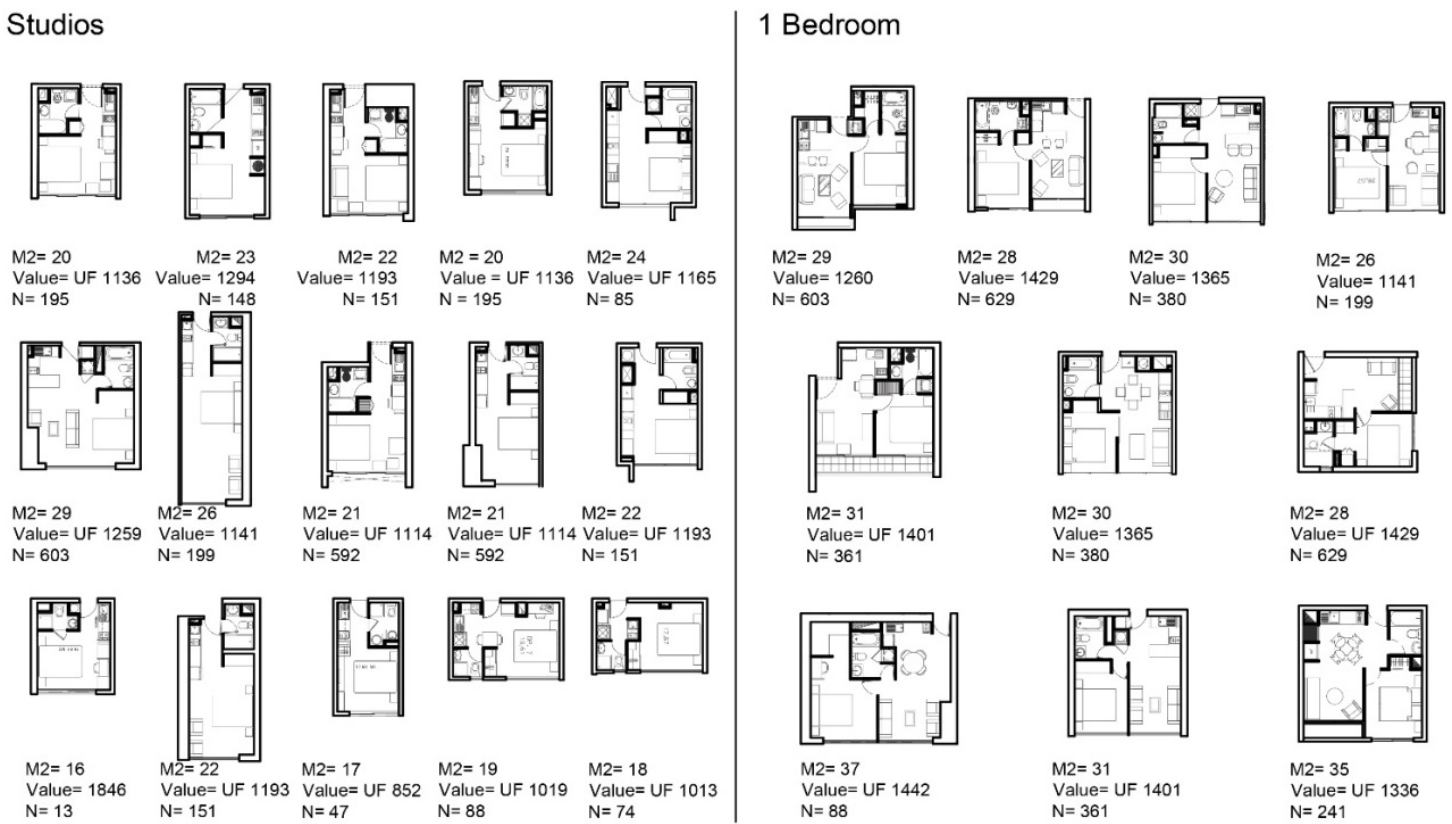

Studio

15-26 m2

Rectangular

Linear

1225 - 1378 UF

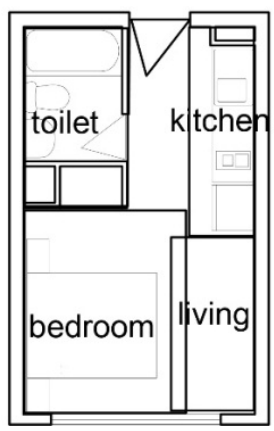

1 Bedroom

29-32 m2

Rectangular

Reduced

Desde 1379 a 1600 UF

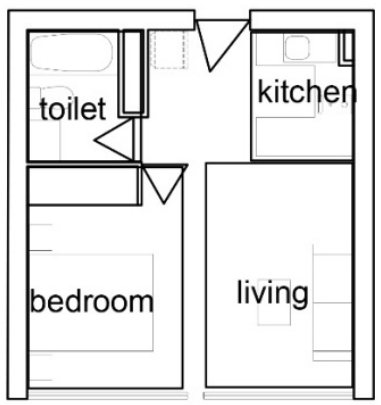

Figure 3. Synthesis of planimetries analyzed and typological results of the housing unit financed in the verticalization model.

\section{Discussion}

The process of housing financialization has a representation in architectural production that facilitates the accumulation of fixed income capital through material assets built to create such wealth that embrace some principles of the financial system, especially regarding the use of debt and the future value of current investment that ensure the growth of financial capital. In practice, the buy-to-let model is based on the principle of stock speculation where the historical trend of the increase in the value of housing (Figure 4) determines that housing is an excellent investment vehicle, for which architecture complies with some elementary principles based on verticalization to maximize the possibility of producing financed housing in the same place, taking maximum advantage of the monopolistic condition of the land location [46] and betting that in the future, sale and rental prices will continue to rise. In this sense, the space of the habitat takes second place as long as there are buyers interested in acquiring these homes as financial assets.

In Chile, different companies have recently initiated property management models by coordinating between investors who want to acquire properties to obtain rent from their lettings and the acquisition of housing units that a low-earning individual will find it difficult to purchase so they will rent it out in order to live near centralities of cities. With this new investment model, the owner does not need to know about the property, so architecture ends up becoming a residual factor in a financial process, with no 
hierarchy other than ensuring the legality of the offer and a spatial arrangement in accordance with existing urban planning and building regulations. In Chile's case, enshrined in the Communal Regulatory Plans and the General Ordinance on Urban Planning and Construction. Nevertheless, for instance, the minimum size of a residential space for a single inhabitant in the Chilean regulatory framework is $15 \mathrm{~m}^{2}$, so regulations are quite flexible for extracting value from investing in housing production.

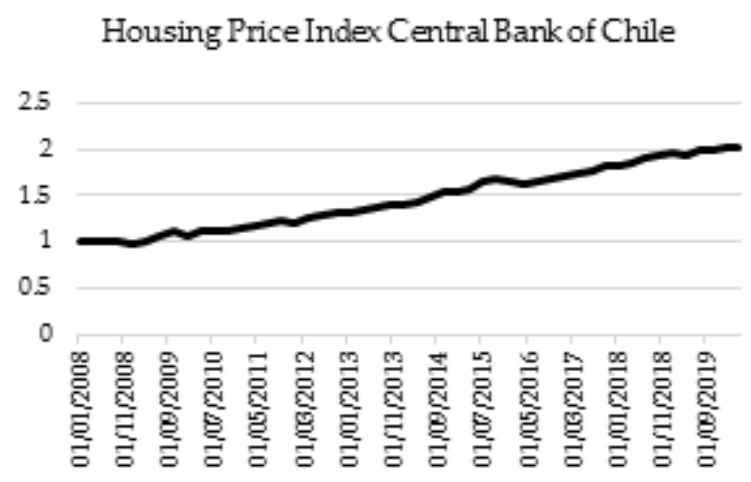

Figure 4. Chilean housing price index from the Central Bank of Chile and Ministry of Housing and Urbanism.

Based on the data, typologies smaller than $37 \mathrm{~m}^{2}$ are reserved for inhabitants outside the commune based on the socio-economic information of the households registered as family groups of two members at most. The main barrier to entry is related to the price of the house after evaluation of the cost of the monthly payment for mortgage loans, as Raquel Rolnik suggests. This allows, on the one hand, verticalization processes to be a way of attracting investors with more secure capital, which allows for some certainty for real estate companies and banks, thus engendering the capitalization of these by investors who do not seek to inhabit the place but to rent it out, as illustrated by Manuel Aalbers. This configuration allows aesthetic concessions that give an identity to financed housing based on an omission of aesthetically ambitious architectural explorations, made up of massive piles of housing without much concern for the development of quality spaces. What matters is quickly selling without much observation of how the products are. This produces an investment in neighborhoods [35] that the residents of the area cannot afford to buy but can access through renting. This contributes to a rise in the income of investors who are not interested in living in that part of the city but are interested in obtaining economic returns at the expense of those who must to live there.

In a model of accumulation of material financial capital in the form of vertically stacked housing, the super-dense Estación Central buildings allow for a review of Graham's thesis on how the neoliberal model tends towards verticalization which obtains significant returns from scarce well-located urban land and the sustained increase in urban population which has created a dynamic of constant demand for new housing. In a financialization scheme, the autonomy of architects under capitalist regimes could not exist in big cities, as Deamer argues, where the interest in creating wealth from architectural products is more important than the design and the habitat itself. Thus, architects working in real estate industries may be compelled to generate models that are not innovative in terms of design, but successful in terms of the placement of fast-selling products in the market by buyers with purchasing power that allows them to ignore the typology in order to focus on the profitability of the products acquired. Undoubtedly, this scenario generates a major disciplinary challenge to rethink architecture in a scheme of respect for the right to habitat over the search for income from new housing marketing processes.

\section{Conclusions}

This article presents a category of analysis of the phenomenon of housing financialization that is developed from architecture as a typology, providing some reflections on the role of the architect when producing housing for financial gain and not necessarily for social good. The findings show, on the one hand, a methodological approach to reviewing this kind of cases in other urban realities, together with a set of new questions to advance in new researches of this kind. A relevant question refers to the transitions that can exist between the architectural scale of the problem of financialization to its planetary scale. That is, how global dynamics end up influencing architects' decision making in the design process. Although this article provides some ideas on this subject, it is important to compare these results with studies based on in-depth interviews with designers of this type of buildings in order to understand their contradictions and reflections from a critical viewpoint. A study based on qualitative thematic analysis or grounded theory can strengthen and complement the results presented here.

A second aspect to be reviewed concerns the inconsistency of revised data corresponding to the architectural projects that were part of this study. In many cases, it was that the Environmental Impact Statements declared different information from the architectural plans and at the same time different from the building permits submitted by the companies for evaluation. This is of concern because, firstly, the competent authority apparently did not detect these inconsistencies given that all the projects reviewed were approved; and secondly, there is a need to look more closely at how companies can have this level of uncoordinated development of large projects. This merits investigations of specific cases based on the development archaeology of each project with mixed methods.

The financialization of the architectural discipline is 
represented in the material space. It designs the projects of low technical quality, without aesthetic reflections or striking spatial explorations. The effect of housing financialization on architecture is represented in a neutralization of the value of the design to allow an empire of profitability based on the placement of typologies that are advantageous for the capital invested rather than for the inhabitants. An analysis that can also follow on from the results of this research should be concerned with public spaces and the modes of urban installation of this model of financed housing in the city, following its logic of intervention in public space, the indoor-outdoor relationship, and the impact on urban systems.

\section{Funding}

This research was funded by ANID-FONDECYT. Grant number: 11180569.

\section{Conflicts of Interest}

The authors declare no conflict of interest.

\section{REFERENCES}

[1] L. Farha, "Financialisation of housing," OHCHR, 2020. [Online]. Available: https://www.ohchr.org/EN/Issues/Hous ing/Pages/FinancializationHousing.aspx. [Accessed: 10-Jan2020].

[2] P. M. Martínez Toro, "The gated communities as urban typology instrumentalized by financialization," Prospectiva, no. 21, p. 25, May 2016.

[3] J. F. Vergara-Perucich and C. Boano, "Vida urbana neoliberal: estudio de factores de jerarquización y fragmentación contra el derecho a la ciudad en Chile," Rev. Direito da Cid., vol. 11, no. 3, pp. 426-452, 2019.

[4] J.-F. Vergara-Perucich and C. Boano, "El derecho a la ciudad financierizada," Bitácora Urbano Territ., vol. 30, no. 3, pp. 123-136, 2020.

[5] R. Fernandez, A. Hofman, and M. B. Aalbers, "London and New York as a safe deposit box for the transnational wealth elite," Environ. Plan. A, vol. 48, no. 12, pp. 2443-2461, 2016.

[6] M. Lullulangi, A. Tawani, and R. Rahmansah, "Architectural Typology of Mamasa Traditional Graves, West Sulawesi, Indonesia," Civ. Eng. Archit., vol. 8, no. 5, pp. 832-837, Oct. 2020. DOI: $10.13189 /$ cea.2020.080510.

[7] F. Yaluff, Los secretos de la inversión inmobiliaria. Santiago: Editorial Un Nuevo Día, 2016.

[8] M. Lukas and E. López-Morales, "Real estate production, geographies of mobility and spatial contestation: A two-case study in Santiago de Chile," J. Transp. Geogr., vol. 67, no.
September 2017, pp. 92-101, 2018.

[9] C. Orrego, "La Burbuja Inmobiliaria que está por estallar en Estación Central 18:45 - 11,” pp. 1-5, 2017.

[10] M.-S. Chien, C.-Y. Cheng, and Y.-C. Hsu, "The Impacts of Financial Freedom on International Real Estate Securities," Univers. J. Account. Financ., vol. 7, no. 4, pp. 83-95, Dec. 2019. DOI: 10.13189/ujaf.2019.070401.

[11] D. Santana-Rivas, "Geografías regionales y metropolitanas de la financiarización habitacional en chile (1982-2015): ¿entre el sueño de la vivienda y la pesadilla de la deuda?," Eure, 2020.

[12]I. Gasic, "Inversiones e intermediaciones financieras en el mercado del suelo urbano. Principales hallazgos a partir del estudio de transacciones de terrenos en Santiago de Chile, 2010-2015," Eure, vol. 44, no. 133, pp. 29-50, 2018.

[13]A. Daher, "Crisis en la producción financiarizada del espacio," Arch. DI Stud. URBANI E Reg., vol. 1, no. 118, pp. 11-32, Feb. 2017.

[14]L. M. López, "El capital inmobiliario-financiero y la producción de la ciudad latinoamericana hoy," Cad. Metrópole, 2020.

[15] E. Stockhammer, "Interview with Engelbert Stockhammer," Rev. la régulation, vol. 10, no. 1, pp. 1-7, 2011.

[16]R. Rolnik, "Late Neoliberalism: The Financialization of Homeownership and Housing Rights," Int. J. Urban Reg. Res., vol. 37, no. 3, pp. 1058-1066, 2013.

[17] R. Rolnik, La guerra de los lugares. La colonización de tierra y la vivienda en la era de las finanzas. Santiago: LOM Ediciones, 2017.

[18] M. B. Aalbers, Subprime Cities: The Political Economy of Mortgage Markets. London - New Jersey: Wiley - Blackwell, 2012.

[19] R. A. Cattaneo Pineda, "Los fondos de inversión inmobiliaria y la producción privada de vivienda en Santiago de Chile: ¿Un nuevo paso hacia la financiarización de la ciudad?," EURE, vol. 37, no. 112, pp. 5-22, Sep. 2011.

[20] J. E. Vergara, "VERTICALIZACIÓN. LA EDIFICACIÓN EN ALTURA EN LA REGIÓN METROPOLITANA DE SANTIAGO (1990-2014)*," Rev. INVI, vol. 32, no. 90, pp. 9-49, 2017.

[21] J. F. Vergara-Perucich and C. Aguirre-Nuñez, "Housing Prices in Unregulated Markets: Study on Verticalised Dwellings in Santiago de Chile," Buildings, vol. 10, no. 1, p. 6, Dec. 2019.

[22] J.-F. Vergara-Perucich and C. Aguirre Nuñez, "Inversionistificación en América Latina: problematización del mercado de arriendo para el caso chileno.," Hábitat y Soc., no. 12 , pp. 11-28, 2019.

[23] G. Therborn, Cities of power: The urban, the nationa, the popular, the global. London - New York: Verso Books, 2017.

[24] R. Weber, "Selling city futures: The financialization of urban redevelopment policy," Econ. Geogr., 2010.

[25] S. Graham, Vertical: the city from satellites to bunkers / Stephen Graham. London - New York: Verso Books, 2016. 
[26] P. Deamer, Architecture and capitalism: 1845 to the present. London - New York: Routledge, 2013.

[27] P. Deamer, The Architect as Worker. 2015.

[28] D. Sudjic, The edifice complex. How the rich and powerful -and their architects- shape the worl. London: Penguin Books, 2006.

[29] S.-O. Wallenstein, Architecture, Critique, Ideology. Writins on Architecture and Theory. Stockolm: Axl Books, 2016.

[30] G. Salazar, Acción Constituyente, 1st ed. Santiago: Tajamar Ediciones, 2020.

[31]F. Sabatini, A. Rasse, G. Cáceres, M. S. Robles, and M. P. Trebilcock, "Promotores inmobiliarios, gentrificación y segregación residencial en santiago de Chile," Rev. Mex. Sociol., vol. 79, no. 2, pp. 229-260, 2017.

[32] D. Maden and P. Marcuse, In Defense of Housing. London New York: Verso, 2016.

[33] L. Lees, "The geography of gentrification: Thinking through comparative urbanism," Prog. Hum. Geogr., vol. 36, no. 2, pp. 155-171, 2012.

[34]J.-F. Vergara-Perucich and C. Aguirre Nuñez, "Inversionistificación en América Latina: problematización del mercado de arriendo para el caso chileno.," Hábitat y Soc., no. 12, pp. 11-28, 2019.

[35] K. Hulse and M. Reynolds, "Investification: Financialisation of housing markets and persistence of suburban socio-economic disadvantage," Urban Stud., vol. 55, no. 8, pp. 1655-1671, 2018.
[36] T. May, Social Research: Issues, Methods and Process, no. Third Edition. 2001.

[37] R. K. Yin, Case study research : design and methods / Robert K. Yin. 2009.

[38] N.-Z. Miguel, "Quantitative Analysis in Social Sciences : A Brief Introduction for non-Economists," pp. 1-20, 2012.

[39] M. Mieles, G. Tonon, and S. Alvarado, "Investigación cualitativa: el análisis temático para el tratamiento de la información desde el enfoque de la fenomenología social," Univ. Humanística, vol. 74, no. 74, pp. 195-226, 2012.

[40] M. del M. Ambiente, "Servicio de Evaluación Ambiental," SEA, 2021. [Online]. Available: https://www.sea.gob.cl/. [Accessed: 20-Dec-2020].

[41]G. H. Baker, Análisis de la Forma, ;: Le Corbusier. Barcelona: Gustavo Gilli, 1997.

[42]F. D. K. Ching, Arquitectra: Forma, Espacio y Orden. Barcelona: Gustavo Gilli, 2015.

[43]A. Prokopska, "Application of Morphological Analysis Methodology in Architectural Design," Acta Polytech., vol. 41 , no. $1,2001$.

[44] G. Rose, Visual Methodologies. London: SAGE Publications, 2001.

[45] Banco Central, "Cuentas Nacionales de Chile 2008-2014," p. $183,2014$.

[46]F. Encinas, C. Aguirre, R. Truffello, and R. Hidalgo, "Speculation, land rent and the neoliberal city. Or why free market is not enough?," Rev. $A R Q$, vol. 1, no. 102, pp. 2-15, 2019. 